\title{
Education Activities to Realize Green Campus
}

\author{
Hilma Tamiami Fachrudin ${ }^{1}$, Khaira Amalia Fachrudin ${ }^{2} \&$ Wahyu Utami ${ }^{1}$ \\ ${ }^{1}$ Department of Architecture, Engineering Faculty, Universitas Sumatera Utara, Indonesia \\ ${ }^{2}$ Department of Management, Economy and Business Faculty, Universitas Sumatera Utara, Indonesia \\ Correspondence: Hilma Tamiami Fachrudin, Department of Architecture, Engineering Faculty, Universitas \\ Sumatera Utara, Indonesia. Tel: 061-821-1633. E-mail: hilma@usu.ac.id
}

Received: June 8, 2019 Accepted: July 18, $2019 \quad$ Online Published: July 23, 2019

doi:10.5539/ass.v15n8p38 URL: https://doi.org/10.5539/ass.v15n8p38

\begin{abstract}
The application of green concepts on campus starts from the formulation of the vision and mission, ratification of policies and development processes. The main problems in the effort to realize a green campus include a lack of involvement and individual awareness of sustainability issues and campus users are unaware of the sustainability that occurs on campus. Individual awareness and involvement of staff and students are needed to create a green campus. The purpose of this study was to analyze what educational activities should be carried out to increase awareness of realizing a green campus. There are several educational activities regarding green concepts aimed to campus users. Education activities such as courses on sustainable environment, research, seminars, student organizations in environmental activities, green campus promotions/campaign and paperless became independent variables in this study. This study uses quantitative methods with Factor analysis. The research was conducted at the Universitas Sumatera Utara. Data was collected by distributing questionnaire forms with respondents as many as 400 students. The results showed that education, practical and seminar activities about the importance of green concepts, green campus campaigns, and green applications on campus such as paperless needed to be done in raising awareness to realize a green campus.
\end{abstract}

Keywords: green campus, green education activity, go-green campaign

\section{Introduction}

The sustainable campus should provide opportunities and incentives for students, lecturers, and staff; students are actively involved in creating sustainable campuses and universities can become the agents of change with far-reaching impact (Emanuel \& Adams, 2011). The concept of sustainability was once tangible and elusive. Yet it remains the most important global challenge of our time. Higher education has the freedom to test and explore new ideas. The campus sustainability plan provides a way to continue the contribution of higher education (White, 2014).

According to Velazquez et al. (2006) in Too and Bajracharya (2015), sustainable universities must begin with the establishment of a vision and mission of sustainability, then build and certify sustainability policies, targets, and goals that are in line with the sustainability mission. The sustainability strategy consists of education, research, outreach, and partnership cooperation and collaboration for waste management, energy, water, and transportation.

University is a place for sustainable concept learning. Formal and informal learning arrangements at universities are relevant to developing competencies for sustainable development (Barth, 2007). The establishment of such a learning culture is enlarging the learning space and facilitating better learning opportunities to develop future-oriented competencies in a variety of different contexts. Sustainable concept learning processes can be done by formal as well as informal organization activities or extra-curricular.

In the research of Zhao and Zou (2015), Tsinghua University's strategy to mobilize green university initiatives can be seen as one principle and three dimensions. Referring to the green campus, which was adopted through universities and disseminated into aspects of daily university operations. Three dimensions refer to green education, green campus and green research, which are practical to realize the principle. The agency of three dimensions in Tsinghua University are: the Green University Initiative Group Leader, namely deputy chairman Tsinghua; the Office of Green University, which coordinate sustainability through various departments, and establish cooperation from off-campus agencies; and The Green Campus Advisory Committee, consisting of 
experts on the green campus who advise the Green University Initiative Group Leader and the Office of Green University.

According to Horhota et al. (2014), sustainability requires long term, policy, and adaptive assessment of resource use and social welfare. There are four obstacles to sustainability behavior, namely: lack of involvement individual awareness of sustainability issues, but not consistently applied; communication issues - alumni and students are less involved and staff from facility services and institutional planning are unaware of the sustainability that occurs on campus; lack of proper campus infrastructure - the inability to use glass on campus, and the inconvenience of cycling or walking on highways between campuses and apartments; and financial concerns - long-term investment returns on "green" is valuable

Colleges and universities can develop a set of methods available to measure their progress internally. Sustainability is an effort for campuses and institutions as well as students to prepare future decisions locally and globally (Horhota et al., 2014).

Green campus minimizes the negative impact on the environment, raises public awareness about sustainability through teaching and research in higher education institutions (Dahle \& Neumayer, 2001). The green campus has been a concern over the last two decades. Education is one of the strategies to promote sustainable concepts (Huyuan \& Yang, 2012). The green university should have a rule of sustainability that implementation on university operational and education procedures. The green campus has some aspects such as operational management and curriculum development (Yeh, 2006).

In the research of Jones (2017) said that the slogan "Go Green" has been adopted by various organizations including businesses and universities in the past few decades. In college academic libraries, as the main service unit in educational institutions, this role becomes a very necessary thing. Some educational libraries implement "Go Green" through green library design, both for new build and renovation. Research conducts university trial projects on waste filling and waste audits to improve waste management efforts and helps understand the impact of pollution as a model that universities are likely to adopt in the future. The results of the study have a strong indicator and need to convey these indicators to staff and students, reminding them of the effectiveness and efficiency of waste management efforts.

Radhakrishnan and Viswanathan (2015) from National University (NU) has actively built internal and external strengths to become a more sustainable green campus institution. It takes an integrated approach to sustainability through administrative leadership, curriculum and research, and community outreach. The high-level university committees on sustainability support and encourage green projects and events. The main objectives of the projects are shown through specific data in the report, relating to declining environmental impacts, savings, and reductions in the fields of energy, water, and waste management.

Campus green space is the most vital and attractive place on campus, and favorable campus landscapes should be able to influence teachers, students and residents in the neighborhood with its spatial form, regional features, and ecological environment, provide them places for outdoor activities, communication and practicing, play a positive role in their life and learning, and also show the historical development. Campus green spaces landscapes are closely related to students' learning and living, influencing their life subtly. To construct campus green landscapes that bring students sense of belonging, kindness, and acceptance, the key is to demonstrate regional characteristic, explore ecological connotations, play the role of science popularization and education, and show the individuality of campus landscape. By the research, Haidian Campus of Hainan University proposed the renovation strategies from the perspective of ecological, regional and unique features, to form the new campus landscape pattern, and provide references for the future construction of campus landscape (Zhang \& Yang, 2017).

\subsection{Education Activities}

Universities and higher education institutions are the most appropriate centers for promoting sustainable development as they can make a unique contribution through the creation of knowledge and communication through student initiatives, research, and outreach programs. Sustainable development now includes three important components that are closely interrelated - ecological integrity, social and economic welfare (Thilagam, 2015). The major components of the campus sustainability plan are: Organization by establish a Sustainability Committee, planning and Project Organization, administrative Management Fund allocation, Project identification and assessment and Awards Council; Operation with natural resource conservation and management: land, water, flora and fauna, and other on-site features and implementation of sustainable planning measure; teaching and Research Sustainable knowledge creation and awareness by documentation and record creation and identify potential research projects; and the last is Outreach by connecting with immediate 
neighborhood; students activity clubs and influence sustainable changes in local communities.

For a campus to achieve sustainable means of development, the following policy formulation is essential for land, energy, waste, transportation, environmental quality, building design and architecture, landscape and ground cover and community interface program. For a community interface program, including provision, expert knowledge, resource sharing, and common local area development programs.

Education criterion based on the idea that universities have an important role to play in promoting sustainability issues (UI GreenMetric, 2015). The sub-indicators are: the number of programs offered is related to the environment and sustainability; the total number of courses offered; the amount of research funding dedicated to environmental research and sustainability (in Dollar AS); the amount of research funding (in Dollar AS); number of scientific publications on the environment and sustainability published; number of scientific events related to the environment and sustainability; number of student organizations related to the environment and sustainability; and the existence of a university sustainability website.

According to Emanuel and Adams (2011), a sustainable college can be defined as a campus that has sustainability criteria, consist of administration - sustainability policies and commitments by campus administrators and trustees; student Involvement - support by campus administrators and student participation in sustainability initiatives; and the Shareholder involvement; opportunities for student, faculty and alumni participation.

In one case on the research by White (2014), in Minnesota State University, Mankato, a group of students prepares their school plans for class projects. Regarding authorship plans, they are usually formed in groups rather than focusing on individuals. In two cases where an individual became the main author who worked for the campus sustainability office. Campus sustainability plans usually bring together individuals and groups from across the campus during their development process. On the other hand, the plan might reflect interest and concern, students, staff, faculty, and administrators. The implementation of the plan elements is not handled consistently but is an identifiable element of most plans. About 22 of the 27 plans are efforts to bring sustainability issues into the course, ranging from comprehensive looks to expanding sustainability content across departments and schools, to more focused goals to offer sustainability certificates and other learning experiences. Eleven plans discuss research specifically, and most of these plans promote the idea of using the campus itself as a focal point for sustainability-oriented research activities.

According to Yeh (2006), there are some related categories with a sustainable campus in university as the references in compiling Green University Evaluation Index System (GUEIS), consists of: sustainability campus plans and policies, operational and management, green purchase, recycling/reuse/reduction, laboratory management, sustainable campus criteria, green curriculum, organization and student activities and community environment. There are some criteria related to educational activities that concluded in environment education such as curriculum, guidelines, activities, research, and instruction.

There are two main aspects to building a green campus, first the physical environment to reduce energy consumption and the carbon footprint and second the socio-cultural aspect which involves management, education, practice and relationship with local communities (Choi et al., 2017). From their research, efforts to establish a physical environment for a green campus can be used as educational materials that students learn about in classes. They are also used in various areas, ranging from student activities to leadership programs, and community programs, for greater participation in green campus initiatives and related education.

According to Tan et al. (2014), the green university concept appears in university operations theory based on the concept of sustainable development, and all work at the university must be organized and implemented from the perspective of the university's long-term sustainability. The sustainable university concern about talent cultivation for sustainability, education, research and disciplines for sustainability. The green campus consists of green masterplan and construction, green operation and management, green technology and regional outreach and green education.

According to Huyuan and Yang (2012), barriers to realizing sustainable university is financial barriers such as funding resources, tight budgets, and expensive costs remain. There is an awareness program consisting of following new and emerging technologies through open lectures, seminars, conferences, research, and workshops; organize smooth and efficient communication to form a feedback loop to engage key stakeholders; convey correct information to the audience and choose an open and well-prepared way to propose the idea of innovation.

Research about green campus and sustainable campus discuss various principles and criteria for creating a green 
campus. One of the criteria used is education. Some educational activities applied to realize the green campus include courses on sustainable environment, research, seminars, student organizations in environmental activities, green campus promotions/campaign and paperless. This research focuses on education activities to realize a green campus.

\section{Method}

Quantitative methods are used to get a recommendation from campus users by survey techniques namely questionnaires and factor analysis using SPSS. The population of this research is undergraduate students in Universitas Sumatera Utara with sample size is 400 students. The independent variables in this research are the education-related green concept. There are thirteen indicators based on previous research and will analyze with factor analysis. The data collected using a survey with a questionnaire technique with a Likert scale interval 1 to 5 from very disagree to very agree. The analysis result is used to measure the effect of educational activities on promotion to realize a green campus.

\section{Results}

This research has thirteen indicators that were part of educational activities in the green campus variable. The analysis was conducted with factor analysis. Based on the factor analysis shows the KMO and Bartlett's Test value namely 0.838 . The value is more than 0.5 means the correlation between variables are accepted (Tabel 1 ). The Bartlett's Test of Sphericity is 0.000 which means fulfill the significance value.

Table 1. KMO and Bartlett's Test of Education Activities

\begin{tabular}{ccc}
\hline Kaiser-Meyer-Olkin Measure of Sampling Adequacy. & .838 \\
\hline Bartlett's Test of Sphericity & Approx. Chi-Square & 2176.761 \\
& df & Sig. \\
\hline
\end{tabular}

The commonalities for education activities show in Table 2. The factor that explains the first variable namely the environmental studies as a compulsory subject is 0.526 or $52.6 \%$. Then, the seminar on green campus held by students is equal to 0.509 or $50.9 \%$, seminar on recycling activities is equal to 0.598 or $59.8 \%$, recycling practice activities is equal to 0.718 or $71.8 \%$, seminar on conservation energy and resources is equal to 0.674 or $67.4 \%$, practical activities regarding the conservation of energy and resources is explained equally to 0.539 or $53.9 \%$. Then, for green campus campaign in the form of banner is explained equal to 0.668 or $66.8 \%$, green campus campaign in the form of poster is equal to 0.734 or $73.4 \%$, green campus campaign in the form of sticker is equal to 0.672 or $67.2 \%$, university has a website about green campus is equal to 0.584 or $58.4 \%$, university held courses about environment is explained equal to 0.498 or $49.8 \%$, university held an environmentally friendly bazaar once a year is explained equally to 0.685 or $68.5 \%$ and university use technological methods in teaching and learning activities to reduce paper consumption (paperless) is equal to 0.583 or $58.3 \%$. The explanation for all variables are an acceptable and fixed factor can be determined.

Table 2. Communalities for Education Activities

\begin{tabular}{lcc}
\hline Communalities & & \\
\hline & Initial & Extraction \\
\hline Environmental studies as a compulsory subject & 1.000 & .526 \\
Seminar on green campus held by students & 1.000 & .509 \\
Seminar on recycling activities & 1.000 & .598 \\
Recycling practice activities & 1.000 & .718 \\
Seminar on conservation energy and resources & 1.000 & .674 \\
Practical activities regarding the conservation of energy and resources & 1.000 & .539 \\
Green campus campaign in the form of banner & 1.000 & .668 \\
Green campus campaign in the form of a poster & 1.000 & .734 \\
\hline
\end{tabular}




\begin{tabular}{lll}
\hline Green campus campaign in the form of a sticker & 1.000 & .672 \\
University has a website about green campus & 1.000 & .584 \\
University held courses about the environment & 1.000 & .498 \\
University held an environmentally friendly bazaar once a year & 1.000 & .685 \\
University reduce paper consumption (paperless) & 1.000 & .583 \\
Extraction Method: Principal Component Analysis. & & \\
\hline
\end{tabular}

The correlation between variables shows in Table 3, where there are three factors and each factor has some indicators. Grouping of indicators in one factor based on their value which is above 0.5 . factors one consists of six indicators that have value above 0.5 , namely environmental studies as a compulsory subject; seminar on green campus held by the student; seminar on recycling activities; recycling practice activities; seminar on conservation energy and resources; and practical activities regarding the conservation of energy and resources. Factor two consists of four indicators, namely green campus campaign in the form of the banner; green campus campaign in the form of the poster; green campus campaign in the form of sticker and university have a website about green campus. Factor three has three indicators which have value above 0.5 namely university held courses about the environment; university held an environmentally friendly bazaar once a year and university reduce paper consumption (paperless).

Table 3. Rotated Component Matrix ${ }^{\mathrm{a}}$

\begin{tabular}{lccc}
\hline & \multicolumn{3}{c}{ Component } \\
\cline { 2 - 4 } Indicator & 1 & 2 & 3 \\
\hline Environmental studies as a compulsory subject & .688 & .088 & .211 \\
Seminar on green campus held by students & .623 & .061 & .343 \\
Seminar on recycling activities & .762 & .119 & -.060 \\
Recycling practice activities & .797 & .219 & .185 \\
Seminar on conservation energy and resources & .742 & .339 & .092 \\
Practical activities regarding the conservation of energy and resources & .607 & .244 & .333 \\
Green campus campaign in the form of banner & .305 & .752 & -.093 \\
Green campus campaign in the form of a poster & .262 & .808 & .111 \\
Green campus campaign in the form of a sticker & .080 & .796 & .178 \\
University has a website about green campus & .093 & .629 & .423 \\
University held courses about the environment & .193 & .451 & .507 \\
University held an environmentally friendly bazaar once a year & .203 & .350 & .722 \\
University reduce paper consumption (paperless) & .172 & -.050 & .742 \\
\hline
\end{tabular}

Extraction Method: Principal Component Analysis.

Rotation Method: Varimax with Kaiser Normalization

a. Rotation converged in 5 iterations

There are three factors in this research, namely factor 1 that relate to education, practical and seminar activities, factor 2 is referred to green campus campaign and factor 3 is called green application on campus. The factors in this research are according to research from Yeh (2006), Huyuan and Yang (2012) Tan et al. (2014), UIGreenmetric (2015) and Choi et al. (2017) who have researched educational activities on the green campus.

All of the factors have a correlation value above 0.5 which means each factor has a strong correlation Table 4). Factor one has a correlation value of 0.686 , factor two has a value of 0.722 and factor three has a correlation value of 0.903 . All of the factors summarize the results of the thirteen variables. 
Table 4. Component Transformation Matrix

\begin{tabular}{ccccc}
\hline Component & 1 & 2 & 3 \\
\hline 1 & .686 & .595 & .419 \\
2 & -.686 & .722 & .097 \\
3 & -.245 & -.354 & .903 \\
\hline
\end{tabular}

Extraction Method: Principal Component Analysis.

Rotation Method: Varimax with Kaiser Normalization.

\section{Discussion}

The application of the green concept on the campus is important to realize. There are three factors in educational activities that can be done to realize a green campus. The first factor relates to education, practical and seminar activities. The activities may be done by students or held by the university. The second factor relates to the green campus campaign that can be held by university and students such as campaign with banner, poster, sticker and promote the green campus concept through the campus website. The third factor relates to the green application on campus that can be in the form of reducing paper use (paperless), a course about the environment that held by university to the community around campus and university held an environmentally friendly bazaar once a year where all academicians and the community can participate in it.

\section{Acknowledgments}

This research is funded by the Competitive Grant Fund from The Indonesian Directorate Research and Community Service Directorate General Strengthens Research and Development, Ministry of Research, Technology and Higher Education, by the research funding agreement and community service in the 2019 budget year Number 11/E1/KP.PTNBH/2019, 29 March 2019.

\section{References}

Barth, M. (2007). Developing Key Competencies for Sustainable Development in Higher Education. International Journal of Sustainability in Higher Education, 8(4), 416-430. https://doi.org/10.1108/14676370710823582

Choi, Y. J., Oh, M., Kang, J., \& Lutzenhiser, L., (2017). Plans and Living Practices for the Green Campus of Portland State University. Sustainability 2017, 9(252), 1-16. https://doi.org/10.3390/su9020252

Dahle, M., \& Neumayer, E. (2001). Overcoming Barriers to Campus Greening: A Survey Among. Education, 2(2), 139-160. https://doi.org/10.1108/14676370110388363

Emanuel, R., \& Adams, J. N. (2011). College Students' Perceptions of Campus Sustainability. The International Journal of Sustainability in Higher Education, 12(1), 79-92. https://doi.org/10.1108/14676371111098320

Horota, M., Asman, J., Stratton, J. P., \& Halfacre, A. C. (2014). Identifying Behavioral Barriers to Campus Sustainability A Multi-Method Approach International. Journal of Sustainability in Higher Education, 15(3), 343-358. https://doi.org/10.1108/IJSHE-07-2012-0065

Huyuan, L., \& Yang, J. (2012). Overcoming Organisational Resistance to Sustainability Innovations in Australian Universities. Proceedings of the 12th Annual Australasian Campuses Towards Sustainability Conference 2012 (pp. 1-10). Brisbane, Australia: Queensland University of Technology.

Jones, L. (2017). More Than Just a Green Building - Developing Green Strategies at the Chinese University of Hong Kong Library. IFLA Green Library Award 2017, 1-14. The International Federation of Library Associations and Institutions.

Radhakrishnan, B. D., \& Viswanathan, S. (2015). National University's Integrated Approach Towards Sustainable-Green Campus: Leadership, Curriculum, and Outreach. Springer International Publishing Switzerland, pp. 75-91. https://doi.org/10.1007/978-3-319-11961-8_7

Tan, H., Chen, S., Shi, Q., \& Wang, L. (2014). Development of Green Campus in China. Journal of Cleaner Production, 64(2014), 646-653. https://doi.org/10.1016/j.jclepro.2013.10.019

Thilagam, N. L. (2015). Integrated Land Use Development for Green Campus. Springer International Publishing Switzerland, 203-214. https://doi.org/10.1007/978-3-319-11961-8_16 
Too, L., \& Bajracharya, B. (2015). Sustainable Campus: Engaging the Community in Sustainability. International Journal of Sustainability in Higher Education, 16(1), 57-71. https://doi.org/10.1108/IJSHE-07-2013-0080

UI GreenMetric. (2015). UI GreenMetric World University Ranking Background of the ranking. Retrieved from http://greenmetric.ui.ac.id/criterian-indicator/

Velazquez, L., Munguia, N., Platt, A., \& Taddei, J. (2006). Sustainable University: What Can Be The Matter?. Journal of Cleaner Production, 14(9/10/11), 810-819. https://doi.org/10.1016/j.jclepro.2005.12.008

White, S. S. (2014). Campus Sustainability Plans in The United States: Where, What, And How to Evaluate?. International Journal of Sustainability in Higher Education, 15(2), 228-241. https://doi.org/10.1108/IJSHE-08-2012-0075

Yeh, S. (2006). Greening the University Campuses in Taiwan: Development of a Green University Evaluation Index System as an Example. Journal of the Chinese Institute of Environmental Engineering, 16(2), 69-81. https://doi.org/10.4090/juee.2007.v1n2.044052

Zhang, R., \& Yang, D. (2017). Analysis and Reform Strategies of Campus Landscape of Hainan University. Journal of Landscape Research, 9(2), 23-27. https://doi.org/10.16785/j.issn1943-989x.2017.2.007

Zhao, W., \& Zou, Y. (2015). Green University Initiatives in China: A Case of Tsinghua University. International Journal of Sustainability in Higher Education, 16(4), 491-506. https://doi.org/10.1108/IJSHE-02-2014-0021

\section{Copyrights}

Copyright for this article is retained by the author(s), with first publication rights granted to the journal.

This is an open-access article distributed under the terms and conditions of the Creative Commons Attribution license (http://creativecommons.org/licenses/by/4.0/). 